\title{
Parasite management in translocations: lessons from a threatened New Zealand bird
}

\author{
John G. Enen, Doug P. Armstrong, Raenyn Empson, Sandra Jack \\ Troy Makan, Kate Mcinnes, Kevin A. Parker, Kate Richardson and \\ Maurice Alley
}

\begin{abstract}
Awareness of parasite risks in translocations has prompted the development of parasite management protocols, including parasite risk assessment, parasite screening and treatments. However, although the importance of such measures seems obvious it is difficult to know whether the measures taken are effective, especially when working with wild populations. We review current methods in one extensively researched case study, the endemic New Zealand passerine bird, the hihi Notiomystis cincta. Our review is structured around four of the 10 questions proposed by Armstrong \& Seddon (Trends in Ecology \& Evolution, 2008: 23, 20-25) for reintroduction biology. These four questions can be related directly to parasites and parasite management and we recommend using this framework to help select and justify parasite management. Our retrospective study of recent disease and health screening in hihi reveals only partial overlap with these questions. Current practice does not focus on, or aim to reduce, the uncertainty in most steps of the risk assessment process or on evaluating whether the measures are effective. We encourage targeted parasite management that builds more clearly on available disease risk assessment methodologies and integrates these tools within a complete reintroduction plan.
\end{abstract}

Keywords Endemic, health screening, hihi, New Zealand, Notiomystis cincta, parasite, reintroduction, stitchbird

JOHN G. EwEN (Corresponding author) and KATE RICHARDSON* Institute of Zoology, Zoological Society of London, Regent's Park, London, NW1 4RY, UK. E-mail john.ewen@ioz.ac.uk

Doug P. ARmStrong Wildlife Ecology Group, Institute of Natural Resources, Massey University, Palmerston North, New Zealand

RAEWYN EMPSON Karori Sanctuary Trust, Wellington, New Zealand

SANDRA JACK Department of Conservation, Auckland Area Office, Devonport, Auckland, New Zealand

Troy MAKAN Forest and Bird, Auckland, New Zealand

Kate MCInNes Department of Conservation, Wellington, New Zealand

Kevin A. PARKer Ecology and Conservation Group, Institute for Natural Sciences, Massey University, Auckland, New Zealand

MAURICE AlLey Institute of Veterinary, Animal and Biomedical Sciences, Massey University, Palmerston North, New Zealand

${ }^{*}$ Also at: Wildlife Ecology Group, Institute of Natural Resources, Massey University, Palmerston North, New Zealand

Received 18 March 2011. Revision requested 16 May 2011.

Accepted 20 June 2011. First published online 30 April 2012.

\section{Introduction}

The prevalence, impacts on individual health and 1 population effects of most parasites on wild hosts are poorly understood. This lack of knowledge is alarming considering that parasites are cited as major threats in conservation (Daszak et al., 2000; Cleaveland et al., 2002; Tompkins \& Poulin, 2006) and that parasite management in translocation programmes has been advocated (Viggers et al., 1993; Cunningham, 1996; IUCN, 1998; Woodford, 2001; Armstrong et al., 2003; Mathews et al., 2006; Parker et al., 2006; Breed et al., 2009). Among the problems we face with regard to these threats are the large number of parasites that can infect each host and the variable effects they have. Predicting which parasites pose major threats is difficult and often environment specific (Tompkins \& Poulin, 2006).

Reintroduction, which involves translocation of organisms, is an important part of conservation management (Griffith et al., 1989; Fischer \& Lindenmayer, 2000). Armstrong \& Seddon (2008) suggested 10 key questions for reintroduction biology and four of these have direct relevance to parasites (questions 2, 3, 8 and 9). When applied specifically to parasite management, the four questions are: (1) how is post-release survival affected by parasites and parasite management, (2) how do parasites affect suitability of release sites, (3) are parasites native to the ecosystem, and (4) how will the ecosystem be affected by the parasites?

Parasite management is often undertaken with little reference information and is subject to high uncertainty. A transparent risk assessment process is therefore required to assess the costs and benefits of any parasite management protocol. The risk assessment process requires input from veterinarians, ecologists and conservation managers to develop an integrated disease management protocol that considers all aspects of the translocation including logistical limitations and monetary cost. Where disease risk is demonstrably high, a higher monetary cost of parasite management may be more palatable to conservation managers if a transparent risk assessment process has been undertaken.

We present results from multiple wild-to-wild reintroductions of the hihi, or stitchbird, Notiomystis cincta consisting of: (1) health and parasite screening, (2) the monetary cost of this screening, and (3) decisions arising from the results obtained. These data encompass all 


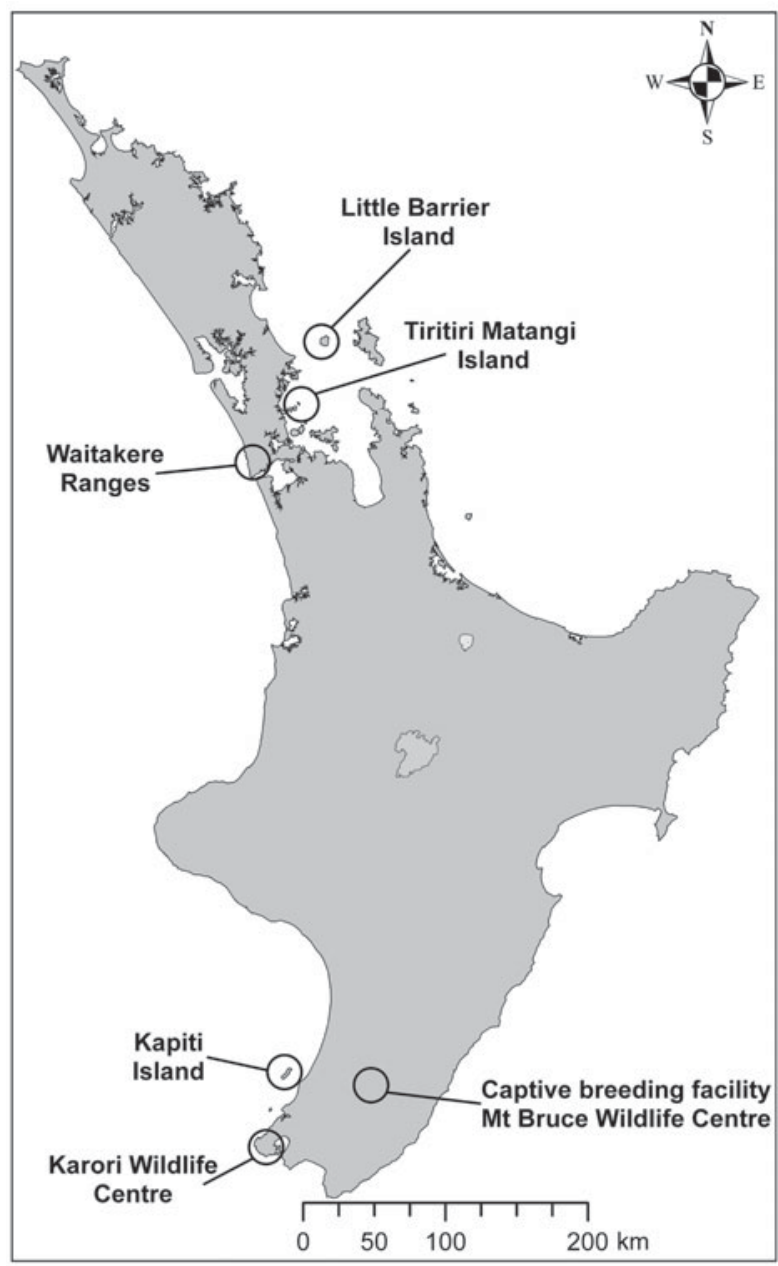

FIG. 1 New Zealand's North Island, showing locations of the remnant population of hihi Notiomystis cincta (Little Barrier), the early reintroduction site of Kapiti, the captive breeding facility at Mt Bruce, and the source population (Tiritiri Matangi) and release locations (Zealandia Karori Wildlife Sanctuary and the Waitakere Ranges) of recent hihi translocations that have incorporated disease screening in the translocation process.

translocations where parasite management has been incorporated as a requirement under New Zealand translocation permits. Our aim is to provide a current perspective of disease risk assessment in reintroduction biology. We hope that using our experience with this species will highlight the reality of the current risk assessment process so that other programmes can avoid similar uncertainty and develop a more efficient approach.

We structure our retrospective review of the parasite screening procedures around the four parasite-related questions of Armstrong \& Seddon (2008). The aim is to provide a logical framework within which parasite management should fit although it was not necessarily how the parasite management process developed in this, or any other, case study. Our methods and results include a summary of original information used to assess disease risk and the health screening and preventative medication given to hihi during translocation. Reviewing current methods within the framework of Armstrong \& Seddon (2008) clarifies the aims of parasite management and highlights where protocols have either met or failed to meet them.

\section{Methods}

Hihi and hihi reintroductions

The population of hihi, an endemic New Zealand passerine, declined from the northern half of the country to become restricted to the offshore island Little Barrier, or Hauturu, $(3,083$ ha) by c. 1890 (Taylor et al., 2005). The hihi is categorized as Vulnerable on the IUCN Red List (BirdLife International, 2008). Conservation management involves translocation of hihi to reintroduce the species to additional sites and the establishment of a captive population at the $\mathrm{Mt}$ Bruce Wildlife Centre. Reintroductions that have incorporated health and parasite screening include the translocation of two groups of hihi from Tiritiri Matangi Island to Zealandia-Karori Wildlife Sanctuary in Wellington (2005) and three groups of hihi from Tiritiri Matangi to the Waitakere Ranges in Auckland (2007 \& 2008; Fig. 1).

The hihi population on Tiritiri Matangi has no immigration or emigration and remains stable at c. 200 adults, with a similar number of juveniles produced each year (the population size is stable because of ongoing harvesting; Armstrong \& Ewen, in press). Translocations from Tiritiri Matangi involving pathogen and healthscreening protocols targeted 191 juvenile and 52 adult birds. We caught all birds at supplementary feeding stations or in mist nets. In each translocation individuals were held in a permanent aviary $(8 \times 6 \times 2.5 \mathrm{~m})$ and a portable aviary $(2.4 \times 1.2 \times 1.8 \mathrm{~m})$ while parasite and health samples were analysed (10-14 days). In all translocations we attempted to obtain screening data from all individuals.

\section{Hazard identification, risk assessment and risk evaluation}

No formal record or publication of an initial disease risk assessment was made for hihi pathogen management during reintroductions. Instead expert judgement was used by representative veterinarians, based predominantly on results from the national necropsy database held at Massey University. Diagnoses of hihi mortalities have been recorded since 1991 and the results of 259 necropsies in individuals aged $>3$ weeks (i.e. not including neonates) are available. We present a summary of disease diagnosis results to assist in the interpretation of parasite screening from wild caught hihi. Additional parasites were also identified as hazards based on expert judgement. Although most disease risk assessment methods rely on scoring systems and judgement to some level, many also advocate a wider 
approach to hazard identification that includes all possible parasites rather than those found in the host species through necropsy (for more details see Armstrong et al., 2003; Miller, 2007; Sainsbury et al., 2012).

Parasite risk assessments were further developed during each subsequent translocation by reviewing previous results. In all cases this process was carried out by consulting veterinarians. Designing protocols that fully met the aims of parasite management was compromised by a lack of information on pathogens present at the source and release sites and by a lack of baseline health data for hihi.

\section{Parasite and health screening protocols}

All birds were weighed and examined for external signs of injury, disease or excessive ectoparasite loads: the mite Ornithonyssus bursa and hippoboscid flies (Diptera, Hippoboscidae). Individuals that passed this check were retained for further health and parasite screening. A blood smear was obtained, fixed in methanol and dried, for examination of blood cell characteristics, including estimated total white blood cell (WBC) count and detection of haemoparasites. We considered estimated total WBC counts important because elevated counts may be associated with aspergillosis (a disease caused by the opportunistic fungal pathogen Aspergillus fumigatus), which is observed frequently in dead hihi and is otherwise difficult to detect in living birds. Elevated counts could also indicate the presence of other previously unreported diseases. During the 2007 and 2008 translocations we collected an additional $70 \mu \mathrm{L}$ of blood for total plasma protein and haematocrit quantification and c. $35 \mu \mathrm{L}$ of blood for polymerase chain reaction (PCR)-based detection of haemoparasites. We also collected a faecal sample that was stored at $4{ }^{\circ} \mathrm{C}$ for detection of intestinal parasites (all translocations) and culture of the enteric bacteria Salmonella, Yersinia spp. and Campylobacter spp. (translocations in 2005 only). In 2007 and 2008 we took cloacal swabs for subsequent culture of Salmonella and Yersinia spp..

\section{Parasite treatment protocols}

In 2005 we medicated all birds retained for translocation with a single oral dose of $20 \mathrm{mg}$ toltrazuril $\mathrm{kg}^{-1}$ (Coccidiocide for Piglets, Baycox, Bayer New Zealand) for the reduction of coccidia, a single oral dose of $10 \mathrm{mg}$ itraconazole $\mathrm{kg}^{-1}$ (Sporanox, Jannsen-Cilag, Australia) as prophylaxis for aspergillosis, and a single oral dose of $4.5 \mathrm{mg}$ pyrantel embonate $\mathrm{kg}^{-1}$ (Combantrin, Pfizer Laboratories, Pfizer New Zealand) and of $10 \mathrm{mg}$ praziquantel $\mathrm{kg}^{-1}$ (Droncit, Bayer New Zealand) to reduce intestinal nematodes, trematodes and cestodes before release into the holding aviary. This treatment was a precautionary measure to minimize the risk of a disease outbreak during captivity and to reduce the potential harmful effects of parasites during the stress of the translocation process. Our selection of the diseases to treat was based on the known endemic diseases of hihi identified by reviewing necropsy findings (Table 1). During the holding period we gave the birds a further daily dose of itraconazole presented in sugar water supplementary feeders at an estimated dosage of $5 \mathrm{mg} \mathrm{kg}^{-1}$ day $^{-1}$. We provided this medication early in the morning for 1 hour during which all other food and water was removed from the aviary. Two days before translocation we provided a second dose of toltrazuril at c. $20 \mathrm{mg} \mathrm{kg}^{-1} \mathrm{day}^{-1}$, also added to the sugar water.

In 2007 and 2008 we provided no direct oral dosage of medication. Our results of faecal analysis from the previous translocation detected few internal parasites, with the exception of coccidia (in only five of 266 individuals screened was Capillaria sp. detected). We therefore treated coccidia by medication in the sugar water, to reduce unnecessary handling stress. Following the capture of all birds required for translocation we provided them with the pig formulation of toltrazuril on 2 consecutive days at a dosage of $0.125 \mathrm{mg} \mathrm{mL}^{-1}$ of sugar water. Starting on the third day and continuing daily until the day before translocation we medicated the birds with itraconazole in the sugar water at an estimated dosage of $5 \mathrm{mg} \mathrm{kg}^{-1}$ day $^{-1}$.

\section{Laboratory analyses and decision framework}

All blood smears, cloacal swabs and faecal samples were examined by a commercial laboratory (Gribbles Veterinary Pathology, Auckland, or the Institute of Veterinary, Animal and Biomedical Sciences, Massey University, Palmerston North; for detailed methods see Parker et al., 2006). Estimated total WBC counts and visual examination for blood parasites were made from each smear. Ten fields of view were examined at $100 \times$ magnification for as long as it took to find 100 white blood cells. WBC differential counts were also made from smears in 2007 and 2008. Bacterial culturing of cloacal swabs or faecal samples was used to test for the presence of Salmonella and Yersinia. Faecal samples were also examined for parasitic eggs as a screen for intestinal parasites (including coccidia and Capillaria sp.). The PCR-based haemoparasite screening from blood samples was undertaken by a commercial contractor, Landcare Research New Zealand, using protocols detailed in Fallon et al. (2003), Hellgren et al. (2004) and Ewen et al. (unpubl. data). The molecular primers used in both protocols allow detection of haemoparasites of Plasmodium, Haemoproteus and Leucocytozoon.

Once disease and health screening results were obtained we made decisions either to translocate or release 
TABle 1 Post-mortem disease diagnosis categories for dead hihi Notiomystis cincta (excluding neonates $<3$ weeks old) submitted to the Institute of Veterinary and Biomedical Sciences between 1991 and 2008. Hihi were submitted from the single captive breeding population and from dead individuals recovered across all monitored wild populations. Data from 1991 to 2000 contain few hihi recovered from wild populations. We present results for the major categories of mortality (contributing $\geqslant 5 \%$ of total records) and report numbers of diagnoses from wild hihi and totals for both wild and captive cases in parentheses.

\begin{tabular}{|c|c|c|c|c|c|c|c|c|c|c|}
\hline & $1991-2000$ & 2001 & 2002 & 2003 & 2004 & 2005 & 2006 & 2007 & 2008 & Total \\
\hline Aspergillosis & 20 & $2(9)$ & $2(4)$ & $0(2)$ & 0 & $1(2)$ & $8(12)$ & $3(6)$ & $5(6)$ & $21(61)$ \\
\hline Coccidiosis & 11 & $0(3)$ & $2(3)$ & $0(2)$ & $0(1)$ & 0 & $2(2)$ & $0(2)$ & $1(2)$ & $5(26)$ \\
\hline Trauma (excluding predation) & 3 & $0(1)$ & $2(3)$ & $0(1)$ & $0(1)$ & $3(5)$ & $2(3)$ & $5(6)$ & $2(3)$ & $14(26)$ \\
\hline Hepatic haemosiderosis & 10 & 0 & $0(1)$ & $1(4)$ & $0(1)$ & $0(1)$ & $2(5)$ & 0 & $1(3)$ & $4(25)$ \\
\hline Bacterial infection & 8 & $0(1)$ & $2(3)$ & $1(1)$ & 0 & $2(2)$ & $2(2)$ & $2(2)$ & $1(2)$ & $7(21)$ \\
\hline Bacterial infection: salmonella* & 0 & 0 & 0 & 0 & 0 & 0 & $6(6)$ & 0 & 0 & $6(6)$ \\
\hline Myocardial/skeletal myonecrosis & 7 & $0(1)$ & $0(2)$ & 0 & $0(1)$ & 0 & $0(1)$ & $1(2)$ & 0 & $1(14)$ \\
\hline Nematodes & 2 & $0(2)$ & $1(1)$ & 0 & 0 & $1(1)$ & $2(2)$ & $2(2)$ & $1(2)$ & $7(12)$ \\
\hline Other & 20 & $1(5)$ & $2(6)$ & $1(3)$ & $1(3)$ & $0(1)$ & $8(10)$ & $7(16)$ & $1(4)$ & $21(68)$ \\
\hline
\end{tabular}

${ }^{\star}$ Denotes a special case of bacterial infection from an outbreak of a novel Salmonella strain in hihi on Tiritiri Matangi Island in 2006 that is treated separately from the general bacterial infection category. There are often multiple disease diagnoses for an individual, in which case the pathologists made a decision on which seemed most important.

individuals back into the source population. Decisions were a mix of stated a priori standards and ad hoc recommendations from veterinary professionals following review of the test results. In all cases we caught and reweighed each bird to determine changes in mass during the holding period.

\section{Results}

Information used to inform hazard identification and risk assessment

Diagnoses of hihi mortalities are shown in Table 1. About two-thirds of cases are from birds held in the captive breeding centre. These data show some clear patterns. Firstly, the most frequent diagnosed disease in both captive and wild hihi was aspergillosis (diagnosed in $24 \%$ of all cases). Secondly, some diagnoses are more prevalent in captive birds, for example myocardial or skeletal myonecrosis (only one of 14 cases was a wild bird), and these diseases are often stress related and catecholamine induced (M. Alley, unpubl. data).

Of the seven major diagnostic categories four have been incorporated into pathogen management through direct screening or preventative treatment (aspergillosis, coccidiosis, bacterial infection and nematodes) and another (trauma) could be avoided barring accidents (Table 2). Two additional pathogen hazards (haemoparasite presence and ectoparasite burden; Table 2) have been identified despite not being detected or noted as causing disease in adult hihi (but see Howe et al., 2012 for a single case of Plasmodium infection causing death in a hihi). They are included because ectoparasitic mites cause nestling mortality in hihi (Ewen et al., 2009) and may be indicative of a generally unhealthy bird, and haemoparasites have been reported to cause the mortality of several native New Zealand bird species (Tompkins \& Gleeson, 2006; Alley et al., 2010).

\section{Assessment of health}

During the 2007 and 2008 translocations five female hihi were not transferred because their weights were $<29 \mathrm{~g}$ by the end of quarantine. This weight is the lower quartile of the capture weight distribution for female hihi and was taken as a potential indicator of poor health and condition. No similar cut-off was used for males.

The most consistently adopted haematological measure was the estimated total WBC count from prepared blood smears ( $\mathrm{n}=130 \mathrm{hihi})$. In the 2005 translocation birds were rejected if estimated total WBC counts (total $\mathrm{WBC} \times 10$ $\left.\mathrm{g} \mathrm{L}^{-1}\right)$ were $\geqslant 20 \times 10 \mathrm{~g} \mathrm{~L}^{-1}(\mathrm{n}=3$ birds). In subsequent translocations an additional three hihi were not translocated because of the blood results; one bird presented with a very low estimated WBC count $\left(2 \times 10 \mathrm{~g} \mathrm{~L}^{-1}\right)$ and the other two had abnormal differential counts and low red blood cell (RBC) counts (see below). In the 2007 and 2008 translocations WBC differential counts were performed on blood smears $(\mathrm{n}=8 \mathrm{o}$ hihi). Differential counts were always made up of a large proportion of lymphocytes and heterophils (66.7 \pm SE $3.3 \%$ and $18.6 \pm$ SE $2.6 \%$, respectively). A single hihi was rejected for translocation because of a presumed high proportion of monocytes.

During the 2007 and 2008 translocations total protein levels and haematocrit volumes were also recorded. No decisions to withhold hihi from translocation were made based on either total protein or haematocrit volume. Two birds (of 80 sampled) were considered anaemic because of low RBC counts. However, no ranges were provided by the commercial screening laboratories. Only one hihi was rejected for translocation based on low RBC count. 
TABLE 2 Pathogen hazards identified in hihi translocations, their justification as a hazard, and methods of diagnosis and treatment.

\begin{tabular}{|c|c|c|c|}
\hline Hazard & Why? & Evaluation & Treatment \\
\hline Aspergillosis & $\begin{array}{l}\text { Most common cause of mortality } \\
\text { in hihi necropsies }\end{array}$ & $\begin{array}{l}\text { Difficult to determine } \\
\text { infection status }\end{array}$ & $\begin{array}{l}\text { Preventative treatment during holding \& } \\
\text { hypothesized link between infection \& elevated } \\
\text { white blood cell counts }\end{array}$ \\
\hline Coccidiosis & $\begin{array}{l}\text { Mortality in hihi but mostly in } \\
\text { captivity }\end{array}$ & $\begin{array}{l}\text { Screening faecal samples for } \\
\text { coccidian occysts }\end{array}$ & $\begin{array}{l}\text { Preventative treatment during holding to reduce } \\
\text { development of disease \& horizontal } \\
\text { transmission }\end{array}$ \\
\hline Bacterial infection & $\begin{array}{l}\text { Mortality in hihi, particularly one } \\
\text { previous salmonellosis outbreak } \\
\text { in source population }\end{array}$ & $\begin{array}{l}\text { Bacterial culture from faecal } \\
\text { material or cloacal swabs }\end{array}$ & $\begin{array}{l}\text { No treatment. If detected, translocation is } \\
\text { cancelled \& infected birds may be treated before } \\
\text { release back into source location }\end{array}$ \\
\hline Nematodes & Previous mortality & Screening faecal samples & $\begin{array}{l}\text { Preventative treatment during holding to reduce } \\
\text { development of disease \& horizontal } \\
\text { transmission }\end{array}$ \\
\hline Haemoparasites & Previously undetected in hihi & $\begin{array}{l}\text { Screening blood smears \& } \\
\text { molecular-based detection }\end{array}$ & $\begin{array}{l}\text { Current confusion of what to do once detection is } \\
\text { positive (see Discussion) }\end{array}$ \\
\hline Ectoparasites & & Visual examination & $\begin{array}{l}\text { In one case treatment with miticide attempted } \\
\text { but in most cases a noticeably heavy ectoparasite } \\
\text { burden resulted in immediate release }\end{array}$ \\
\hline
\end{tabular}

\section{Question 1: how is post-release survival affected by parasite management?}

The current disease risk assessment process makes no requirement for post-release monitoring to evaluate the effects of parasites or parasite management. Few hihi died or were injured as a result of capture and handling during transfer. Of 243 hihi caught for translocation, one died from blood sampling (blood loss), one was killed following a broken leg caused by capture, one died in captivity from a suspected head trauma injury, one died possibly as a result of intraspecific aggression while in captivity, one had a broken maxilla tip that may have occurred during capture and one had a temporarily prolapsed cloaca caused by swabbing.

As determined by weight change, holding hihi in captivity for 10-14 days seemed to cause little distress. One hundred and ninety-seven hihi had their weights recorded at capture and again following quarantine and, on average, gained weight during this period $(t=3.01, \mathrm{df}=195$, $\mathrm{P}<0.01$ ). Although not conclusive, weight gain suggests that current husbandry practice is suitable for maintaining hihi in captivity. However, some individuals may cope particularly poorly with captivity or lose condition rapidly because of disease, as extreme weight loss of up to $8 \mathrm{~g}(21 \%$ of body weight) was observed.

Question 2: how do parasites affect suitability of release sites?

The suitability of release sites for hihi is difficult to determine because there is little available information on parasites already present at these sites. There is no requirement to survey release locations for parasites before reintroduction. There is a recommendation that spore counts of Aspergillus sp. within soil at release sites be low $(<100,000$ Colony Forming Units per gram of soil $)$ given previous evidence for poor population viability in habitats with high spore counts (Taylor et al., 2005; Armstrong et al., 2007; Perrott \& Armstrong, 2011). Neither release site assessed spore counts in the planning phase of hihi reintroduction, partly because of the difficulties in doing this and in determining the appropriate sampling scale, both spatial and temporal.

\section{Question 3: are parasites native to the ecosystem?}

Limited information is available to judge the probability that parasites detected on hihi are native at source and release sites. There are two likely exceptions. Firstly, ectoparasitic mites (O. bursa) and/or hippoboscid flies (Diptera, Hippoboscidae) were detected frequently (mean $23 \pm$ SE $4.8 \%$ of all birds). Both are generalist and widespread parasites of birds in New Zealand and elsewhere (Boyd, 1951; Walter \& Proctor, 1999) and are likely to be present at both source and release sites. In our sample no birds presented abnormal infestations and none were rejected from translocation because of the presence of ectoparasites. In one translocation the presence of mites resulted in treatment of the bird with the paraciticide Frontline Spray (Merial Ancare, New Zealand). The long-term effectiveness of these treatments in adult hihi is unknown but at minimum they reduce the current ectoparasite load.

Secondly, intestinal coccidia are generally regarded as host specific (Kawahara et al., 2008) and are frequently found in hihi through analysis of faecal samples (Table 3). 
TABLE 3 Results from visual examination of single faecal samples for endoparasitic eggs in adult hihi during background disease surveillance and quarantine disease assessment linked to translocation. Two endoparasites were found in faecal screens. Mean and median scores are presented when recorded and are in eggs per $g$ of faecal material.

\begin{tabular}{|c|c|c|c|c|c|c|c|}
\hline \multirow[b]{2}{*}{ Year } & \multirow[b]{2}{*}{ Month } & \multirow[b]{2}{*}{ Island } & \multirow[b]{2}{*}{$\mathrm{N}$} & \multicolumn{3}{|l|}{ Coccidia sp. } & \multirow{2}{*}{$\begin{array}{l}\text { Capillaria } \\
\text { sp. positiv }\end{array}$} \\
\hline & & & & No. positive (\%) & Mean & Median & \\
\hline \multirow[t]{3}{*}{2004} & Jan. & Little Barrier & 27 & $6(22)$ & 223 & 116 & 1 \\
\hline & Jan./Feb. & Kapiti & 11 & 0 & 0 & 0 & 1 \\
\hline & Jan./Feb. & Tiritiri Matangi & 28 & $7(25)$ & 3,189 & 262 & 3 \\
\hline \multirow[t]{2}{*}{2005} & Feb. & Tiritiri Matangi & 34 & $17(50)$ & 5,430 & 250 & 0 \\
\hline & May & Tiritiri Matangi & 37 & $18(49)$ & 5,583 & 911 & 0 \\
\hline \multirow[t]{2}{*}{2007} & Feb. & Tiritiri Matangi & 34 & 0 & & & 0 \\
\hline & June & Tiritiri Matangi & 30 & 0 & & & 0 \\
\hline 2008 & May & Tiritiri Matangi & 65 & $30(46)$ & & & 0 \\
\hline
\end{tabular}

The prevalence of coccidian infections was $0-50 \%$ (mean $24 \pm$ SE $7.4 \%$ ) across the translocations and previous sampling from Tiritiri Matangi Island. Coccidia were also detected with a similar prevalence in the remnant population on Little Barrier, suggesting they are native and have been transferred during previous reintroductions. Infection intensity with coccidia was highly variable, with a mean shedding rate of 5,583 eggs $\mathrm{g}^{-1}$ of fresh faeces in May 2005 (Table 3).

Question 4: how will the ecosystem be affected by the parasites?

No post-release monitoring has occurred in the wider ecosystem of release sites to judge the effects of any cotranslocated parasites. However, based on known host generality of the parasites and an unknown geographical distribution, two groups of parasites were considered high risk if co-translocated to the release ecosystem.

Firstly, haemoparasite lineages may not be shared between source and release locations and some of these parasites are host generalists and can cause disease. No blood smears showed evidence of haemoparasite infection but molecular methods did show evidence of infection with a Plasmodium-type haemoparasite in seven of 69 individuals during the 2008 translocation. None of these birds were subsequently moved and at least five of them remained alive and subsequently bred. In a more recent translocation in 2010 one juvenile hihi died during temporary holding due to infection with a Plasmodium relictum parasite (strain type GRW4; Howe et al., 2012).

Secondly is a group comprising the enteric bacteria Salmonella and Yersinia. Salmonellosis has been recorded in the hihi on Tiritiri Matangi and caused substantial mortality (see Discussion). Neither bacterium, however, has been isolated from cloacal swabs and faecal material (243 hihi over 4 sampled years on Tiritiri Matangi, 27 hihi in 2004 on Kapiti Island, and 29 hihi in 2004 on Little Barrier Island).

\section{Cost and outcome}

Disease screening costs made up a substantial component of direct translocation costs (Table 4). Costs were reduced as much as possible by relying on volunteers and in-kind contributions. Parasite screening expenses are largely encompassed by the commercial screening of samples, with little spent on consumables and staff time at the capture/quarantine site. Disease screening resulted in 25 birds being rejected from translocation, of which eight failed the physical external examination (Table 5). Some costs could have been further reduced by pooling samples and we have not estimated the costs of the ongoing necropsy database because it is under a more general, ongoing contract between the Department of Conservation and Massey University.

\section{Discussion}

Health and parasite screening in translocations is a relatively new endeavour (Cunningham, 1996; IUCN, 1998; Armstrong et al., 2003; Mathews et al., 2006; Miller, 2007). Although these procedures are important screening does not guarantee that parasite-free individuals are being moved, that post-release survival will be improved or that the risk of introducing undesirable parasites to new sites is eliminated.

While trying to answer Armstrong \& Seddon's (2008) four questions we must recognize the constraints. We have, for example, a restricted armoury of tests and little background information on the parasites in the host species being translocated. Furthermore we may not have information on whether the parasites we target for management are present at the release site, whether parasites already at the release site may compromise translocation success or what impacts translocated parasites will have on other species. This is not restricted to hihi. A recent review has shown similar conclusions from a wide variety of vertebrate and invertebrate host species in reintroduction biology 
TABLE 4 Financial cost in NZD of the various components of each translocation. Disease screening varied depending on the number of samples gathered and the tests performed (see Methods). $\mathrm{N}$ is the total number of birds available for testing although not all birds provided samples for all tests. Staff costs are estimated from ecologist contractor rates charged to run more recent reintroductions of hihi on Tiritiri Matangi because this role was undertaken by experienced staff donating time to the reintroductions detailed here. The zero cost for post-release monitoring means this task was combined into an established role at the site and no extra money was allocated.

\begin{tabular}{lrr}
\hline Translocation/component & N & Cost (NZD) \\
\hline Karori Sanctuary 2005 & 83 & \\
Estimated coordinating staff cost & & 5,000 \\
Transfer logistics & & 5,000 \\
Disease screening & 3,162 \\
Post-release monitoring & 0 \\
Total & 35 & 13,162 \\
Waitakere Ranges Feb. 2007 & \\
Estimated coordinating staff cost & & 5,000 \\
Transfer logistics & & 1,888 \\
Disease screening & & 5,148 \\
Post-release monitoring & & 8,420 \\
Total & & 20,456 \\
Waitakere Ranges May 2007 & 38 & \\
Estimated coordinating staff cost & & 5,000 \\
Transfer logistics & & 623 \\
Disease screening & & 5,200 \\
Post-release monitoring & & 9,251 \\
Total & & 20,074 \\
Waitakere Ranges May 2008 & 69 & \\
Estimated coordinating staff cost & & 5,000 \\
Transfer logistics & & 1,592 \\
Disease screening & & 9,699 \\
Post-release monitoring & \\
Total & & 0,291 \\
\hline
\end{tabular}

(Ewen et al., 2012). Holding wild animals in captivity for pathogen management also induces social and environmental stress that may itself lower post-release survival (Dickens et al., 2010). We have reviewed our hihi case study relative to each of Armstrong \& Seddon's (2008) four questions and evaluated the disease risk assessment protocols presented here.

\section{Question 1: how is post-release survival affected by parasite management?}

A glaring gap in the current parasite management process is the failure to monitor post-release survival. Again this is not restricted to hihi. In most ad hoc reports of parasite management and post-release mortality there is a recognition that our information is limited (Ewen et al., 2012). Furthermore, where any formal disease risk assessment has been undertaken (in any host species) there is currently no inclusion of a targeted monitoring post-release to inform effectiveness of parasite management (Sainsbury et al., 2012).

In hihi translocations for example, parasite and health screening is meant to select only healthy individuals, to maximize immediate post-release survival. The effectiveness of this strategy is currently not estimated although it is the focus of ongoing research. In all translocations we encourage the integration of parasite management into the wider translocation plan such that its aims can be set against targeted monitoring and the feedback used to inform its effectiveness and optimize its approach. This form of adaptive management is advocated in reintroduction biology (Armstrong \& Reynolds, 2012) but has never been used for parasite management in reintroduction (Sainsbury et al., 2012).

Question 2: how do parasites affect suitability of release sites?

Currently the only pathogen of concern in selecting release sites for hihi reintroduction is the opportunistic A. fumigates. This is not an infectious agent and normally causes disease as a secondary infection in immunosuppressed individuals. The best way of reducing the impacts of aspergillosis may be to translocate generally healthy birds, reduce stress during translocation and select release sites with low spore counts. As with criticisms under question 1, no effective tests of these claims have been made and they are not built into current effective monitoring and evaluation programmes. In other reintroduction programmes the presence of parasites has resulted in rejecting release sites. These restrictions are justified when the problem parasite causes disease at such a frequency that reintroduced host populations will not be able to coexist. For example, the canine distemper virus and Yersinia pestis are widespread in the historic range of the threatened blackfooted ferret Mustela nigripes, which requires careful release site selection to avoid areas of high pathogen prevalence in alternative hosts (Williams et al., 1994; Antolin et al., 2002; Gober, 2008).

\section{Question 3: are parasites native to the ecosystem?}

We judged intestinal coccidia as probably native to the ecosystem in hihi translocations because they are considered host specific. Coccidia are most often detected as asymptomatic chronic infections, although post-mortem analyses have diagnosed coccidiosis in five wild birds ( $6 \%$ of all wild bird cases) and in many more held permanently in captivity (Table 1; Cork et al., 1999). A logistical complication in screening coccidia is that hihi are confined in communal aviaries where parasite transmission can occur through oral 
TABLE 5 Reasons birds were rejected from translocation.

\begin{tabular}{llllllllll}
\hline & $\begin{array}{l}\text { No. } \\
\text { caught }\end{array}$ & $\begin{array}{l}\text { No. } \\
\text { rejected }\end{array}$ & Surplus & $\begin{array}{l}\text { Physical } \\
\text { examination }\end{array}$ & Died & $\begin{array}{l}\text { Blood cell count } \\
\text { celood }\end{array}$ & $\begin{array}{l}\text { Bloosite } \\
\text { parascidia }\end{array}$ & Bacteria \\
\hline Karori Feb. 2005 & 40 & 10 & 8 & 0 & 0 & 0 & 0 & 2 & 0 \\
Karori May 2005 & 43 & 13 & 7 & 0 & 2 & 3 & 0 & 1 & 0 \\
Waitakere Feb. 2007 & 35 & 5 & 0 & 3 & 0 & 2 & 0 & 0 & 0 \\
Waitakere May 2007 & 38 & 9 & 7 & 0 & 0 & 2 & 0 & 0 & 0 \\
Waitakere May 2008 & 69 & 13 & 0 & 5 & 1 & 0 & 7 & 0 \\
\hline
\end{tabular}

ingestion of contaminated faecal material. Given that the risk to other species from this parasite is low, screening for coccidia has been discontinued. However, it is assumed that a proportion of birds will be infected and thus preventative treatment is provided during captivity to minimize disease emergence. A similar approach was used recently in reintroductions of cirl bunting Emberiza cirlus in the UK, with the a priori aim of maintaining intestinal coccidia in the establishing populations (McGill et al., 2010).

Question 4: how will the ecosystem be affected by the parasites?

Again there is little information in hihi reintroductions of the ramifications of any co-introduction of parasites. Although host-specific parasites should pose little threat, in some cases it can be difficult to determine which parasites are capable of host switching. Two groups of parasites were deemed high risk in hihi reintroduction because of their ability to switch host.

Firstly, screening for haemoparasites provided concern when seven hihi tested positive to an unspecified Plasmodium parasite, using PCR. This resulted in a confused response. Some personnel encouraged translocation of these birds, yet they were rejected for translocation by the project leader. Justification to move these birds was based on Plasmodium parasites being detected in another host species on Tiritiri Matangi (bellbird Anthornis melanura; Barraclough et al., in press) with no obvious pathogenicity. The suggestion to move parasitized hihi highlights a lack of contingency planning and a clear statement of aims. For example, if the intention was to gain reference information then this should have been stated a priori to avoid confusion between different stakeholders. A lesson learned from this is that before any screening is undertaken there must be stated ramifications following a positive result. Post hoc decisions are not acceptable where a clear a priori request for screening is made. This is even more important given the financial costs and the extended time birds are in quarantine while test results are pending.

Secondly, screening of hihi continues for Salmonella enterica serotype Typhimurium DT195. This pathogen, however, was only detected from necropsy examination during the February 2006 outbreak (Ewen et al., 2007). The source of this bacterium is unknown and there must be an alternative reservoir host, or risk pathway, that could provide a source of infection into the hihi population in the future. Generalist pathogens with high virulence justify greater investment in screening as they can affect alternative hosts present at release sites. A problem with pathogens that behave in this way is that they are often difficult to detect because susceptible individuals die quickly. It may be, however, that the pathogen is present at levels below the pathogenic dose or that some of a population become resistant and act as carriers (Palmgren et al., 2006). S. enterica serotype Typhimurium DT195 remains a highrisk pathogen but it does not seem to have established as a sustained infection in hihi.

Published examples of ecosystem effects of parasite co-introduction are rare in reintroduction biology (reviewed in Ewen et al., 2012). One such example involves the accidental co-introduction of Batrachochytrium dendrobatidis, the pathogen causing the disease chytridiomycosis, in the Mallorcan midwife toad Alytes muletensis, from a captive-breeding facility that had been used for reintroducing this species to the wild (Walker et al., 2008). However, the most sobering examples come from host species introductions where now infamous cases highlight the sometimes disastrous consequences of exotic parasite establishment (Plowright, 1982; van Riper et al., 1986; Tompkins et al., 2002).

\section{Qualitative disease risk assessment and parasite management}

The disease risk assessment process for hihi reintroductions failed at the initial step of providing transparency to the process. With no formal documentation of the disease risk assessment it remains difficult to evaluate the criteria and justification of decisions made. This is a key factor of the risk assessment process (Armstrong et al., 2003; Miller, 2007; Sainsbury et al., 2012). Perhaps associated with this we faced numerous problems with the process and suggest that: (1) the aims of disease screening need to be clearly stated a priori, (2) justification is needed for each test, including the acknowledgement of any limitations of test results, and 
(3) responses to potential test results need to be decided a priori. Having a contingency plan in place for nonfavourable results allows a rapid response and forces the decision process to be thought through carefully rather than being reactionary. Furthermore, multiple general health assessments (clinical pathological parameters) can be useful for evaluating the health of a bird. However, interpretation will be much more valuable if results are related directly to post-release survival (e.g. Mathews et al., 2006). Total protein levels and haematocrit volumes are examples of tests made on hihi that could benefit from this additional information; their value needs consideration against the costs of carrying out the tests (c. NZD 14.50 per bird).

\section{Management implications}

Using the information available from these hihi reintroductions and information that was used to inform initial disease risk assessments we recommended reducing the parasite screening and health testing, which provided little utility. We recommend at least assessing standard health measures of weight and estimated total WBC counts to select generally healthy birds for translocation (along with their parasites). We must maintain vigilance for Salmonella serovars (by detailed monitoring of the source population before reintroduction and/or individual bacterial screens) given the potential for this pathogen to infect other hosts. This approach reduces costs. Maximal health and pathogen screening costs for each bird amount to c. NZD 190 and this can be reduced to NZD 58 with bacterial screens. Implementation of these protocols in a more recent hihi translocation also reduced the quarantine time from $>10$ to c. 3 days (Ewen et al., 2011).

More importantly we encourage a committed and formalized approach to valid, useful and transparent disease risk assessments. A recent summary of these approaches is provided by Sainsbury et al. (2012) who concluded that despite some detailed methodology of the disease risk assessment process there are few published examples of its use in reintroduction biology. Integrating parasite management more fully into the reintroduction programme will help to promote clear goal setting and strategies to assess the effectiveness of these management options. We have attempted to introduce the relevant framework by using Armstrong \& Seddon's (2008) key questions in reintroduction biology as an overarching framework. Adaptive management provides an additional strong framework that is especially suitable for parasite management given the level of uncertainty faced throughout the process (see Sainsbury et al., 2012 for more detail). However, our critique needs to be placed in context. Parasite management in reintroduction biology is a recent development and the techniques and methods are being continually refined. The risks posed by parasites and addressed by the four questions considered here are real, albeit poorly understood. Only through ongoing implementation, evaluation and review will this process be refined.

\section{Acknowledgements}

We thank the New Zealand Department of Conservation and the Hihi Recovery Group for support. We especially thank the conservation groups who paid for and supplied the disease screening data for this study: Karori Sanctuary Trust, and Forest and Bird's Ark in the Park project. This research was supported by a Research Councils UK Fellowship to JGE and a Forest and Bird contract to TM. We thank Dan Tompkins and anonymous referees for their constructive criticism. All procedures used were permissible by authority of the New Zealand Department of Conservation (permit numbers WE/156/FAU and AK-23042-FAU).

\section{References}

Alley, M.R., Hale, K.A., Cash, W., Ha, H.J. \& Howe, L. (2010) Concurrent avian malaria and avipox virus infection in translocated South Island saddlebacks (Philesturnus carunculatus carunculatus). New Zealand Veterinary Journal, 58, 218-223.

Antolin, M.F., Gober, P., Luce, B., Biggins, D.E., van Pelt, W.E., SEERY, D.B. et al. (2002) The influence of sylvatic plague on North American wildlife at the landscape level, with special emphasis on black-footed ferret and prairie dog conservation. In Transactions of the 67th North American Wildife and Natural Resources Conference (ed. J. Rahm), pp. 104-127. Wildlife Management Institute, Washington, DC, USA.

Armstrong, D.P., Castro, I. \& Griffiths, R. (2007) Using adaptive management to determine requirements of re-introduced populations: the case of the New Zealand hihi. Applied Ecology, 44, 953-962.

Armstrong, D.P. \& Ewen, J.G. (in press) Consistency, continuity and creativity: long-term studies of population dynamics on Tiritiri Matangi Island. New Zealand Journal of Ecology.

Armstrong, D., Jаков-Hoff, R. \& Seal, U.S. (eds) (2003) Animal Movements and Disease Risk: A Workbook. Conservation Breeding Specialist Group (Species Survival Commission/IUCN), Apple Valley, USA.

Armstrong, D.P. \& Reynolds, M.H. (2012) Modelling reintroduced populations. In Reintroduction Biology: Integrating Science and Management (eds J.G. Ewen, D.P. Armstrong, K.A. Parker \& P.J. Seddon), pp. 165-222. Wiley-Blackwell, Oxford, UK.

Armstrong, D.P. \& Seddon, P.J. (2008) Directions in reintroduction biology. Trends in Ecology \& Evolution, 23, 20-25.

Barraclough, R.K., Cope, T., Peirce, M.A. \& Brunton, D.H. (in press) First example of a highly prevalent but low-impact malaria in an endemic New Zealand passerine: plasmodium of Tiritiri Matangi Island bellbirds (Anthornis melanura). Studies in Avian Biology.

Birdife International (2008) Notiomystis cincta. In IUCN Red List of Threatened Species v. 2011.2. Http://www.iucnredlist.org [accessed 9 March 2012].

Boyd, E.M. (1951) The external parasites of birds: a review. Wilson Bulletin, 63, 363-369. 
Breed, A.C., Plowright, R.K., Hayman, D.T.S., Knobel, D.L., Molenaar, F.M., Gardner-Roberts, D. et al. (2009) Disease management in endangered mammals. In Management of Disease in Wild Mammals (eds R.J. Delahay, G.C. Smith \& M.R. Hutchings), pp. 215-240. Springer, New York, USA.

Cleaveland, G.R., Hess, G.R., Dobson, A.P., Laurenson, M.K., McCallum, H.I., Roberts, M.G. \& Woodroffe, R. (2002) The role of pathogens in biological conservation. In The Ecology of Wildlife Diseases (eds P.J. Hudson, A. Rizzoli, B.T. Grenfell, H. Heesterbeek \& A.P. Dobson), pp. 139-150. Oxford University Press, Oxford, UK.

Cork, S.C., Alley, M.R., Johnstone, A.C. \& Stockdale, P.H.G. (1999) Aspergillosis and other causes of mortality in the stitchbird in New Zealand. Journal of Wildlife Diseases, 35, 481-486.

Cunningham, A.A. (1996) Disease risks of wildlife translocations. Conservation Biology, 10, 349-353.

Daszak, P., Cunningham, A. \& Hyatt, A.D. (2000) Emerging infectious diseases of wildlife-threats to biodiversity and human health. Science, 287, 443-449.

Dickens, M.J., Delehanty, D.J. \& Romero, L.M. (2010) Stress: an inevitable component of animal translocation. Biological Conservation, 143, 1329-1341.

Ewen, J.G., Acevedo-Whitehouse, K., Alley, M., Carraro, C., Sainsbury, A.W., Swinnerton, K. \& Woodroffe, R. (2012) Empirical consideration of parasites and health in reintroduction. In Reintroduction Biology: Integrating Science and Management (eds J.G. Ewen, D.P. Armstrong, K.A. Parker \& P.J. Seddon), pp. 290-335. Wiley-Blackwell, Oxford, UK.

Ewen, J.G., Parker, K.A., Richardson, K., Armstrong, D.P. \& Smuts-Kennedy, C. (2011) Translocation of hihi Notiomystis cincta to Maungatautari, a New Zealand mainland reserve protected by a predator-exclusion fence. Conservation Evidence, 8, 58-65.

Ewen, J.G., Thorogood, R., Brekke, P., Cassey, P., Karadas, F. \& Armstrong, D.P. (2009) Maternally invested carotenoids compensate costly ectoparasitism in the hihi. Proceedings of the National Academy of Sciences of the USA, 106, 12798-12802.

Ewen, J.G., Thorogood, R., Nicol, C., Armstrong, D.P. \& Alley, M.R. (2007) Salmonella Typhimurium in hihi, New Zealand. Journal of Emerging Infectious Diseases, 13, 788-790.

Fallon, S.M., Ricklefs, R.E., Swanson, B.L. \& Bermingham, E. (2003) Detecting avian malaria: an improved polymerase chain reaction diagnostic. Journal of Parasitology, 89, 1044-1047.

Fischer, J. \& Lindenmayer, D.B. (2000) An assessment of the published results of animal relocations. Biological Conservation, 96, $1-11$.

Gober, J. (2008) U.S. Fish and Wildlife Service 5-Year Review of the Black-Footed Ferret. U.S. Fish and Wildlife Service, South Dakota Field Office, Pierre, USA.

Griffith, B., Scott, J.M., Carpenter, J.W. \& Reed, C. (1989) Translocation as a species conservation tool: status and strategy. Science, 245, 477-480.

Hellgren, O., Waldenström, J. \& Bensch, S. (2004) A new PCR assay for simultaneous studies of Leucocytozoon, Plasmodium, and Haemoproteus from avian blood. Journal of Parasitology, 90, 797-802.

Howe, L., Castro, I.C., Schoener, E.R., Hunter, S., Barraclough, R.K. \& Alley, M.R. (2012) Malaria parasites (Plasmodium spp.) infecting introduced, native and endemic New Zealand birds. Parasitology Research, 110, 913-923.

IUCN (1998) Guidelines for Reintroductions. IUCN/Species Survival Commission Reintroduction Specialist Group, Gland, Switzerland.

Kawahara, F., Taira, K., Nagai, S., Onagu, H., Onuma, M. \& Nunova, T. (2008) Detection of five avian Eimeria species by species-specific real-time polymerase chain reaction assay. Avian Diseases, 52, 652-656.

Mathews, F., Moro, D., Strachan, R., Gelling, M. \& Buller, N. (2006) Health surveillance in wildlife reintroductions. Biological Conservation, 131, 338-347.

McGill, I., Feltrer, Y., Jeffs, C., Sayers, G., Marshall, R.N., PeIRCE, M.A. et al. (2010) Isosporoid coccidiosis in translocated cirl buntings (Emberiza cirlus). Veterinary Record, 167, 656-660.

Miller, P.S. (2007) Tools and techniques for disease risk assessment in threatened wildlife conservation programmes. International Zoo Yearbook, 41, 38-51.

Palmgren, H., Aspán, A., Broman, T., Bengtsson, K., Blomquist, L., Bergström, S. et al. (2006) Salmonella in black-headed gulls (Larus ridibundus); prevalence, genotypes and influence on Salmonella epidemiology. Epidemiology and Infection, $134,635-644$.

Parker, K.A., Brunton, D.H. \& Jаков-Hoff, R. (2006) Avian translocations and disease; implications for New Zealand conservation. Pacific Conservation Biology, 12, 155-162.

Perrott, J.K. \& Armstrong, D.P. (2011) Aspergillus fumigatus densities in relation to forest succession and edge effects: implications for wildlife health in modified environments. EcoHealth, 8, 290-300.

Plowright, W. (1982) The effects of rinderpest and rinderpest control on wildlife in Africa. Symposium of the Zoological Society of London, $50,1-28$.

Sainsbury, A.W., Armstrong, D.P. \& Ewen, J.G. (2012) Methods of disease risk analysis for reintroduction programmes. In Reintroduction Biology: Integrating Science and Management (eds J.G. Ewen, D.P. Armstrong, K.A. Parker \& P.J. Seddon), pp. 336-359. Wiley-Blackwell, Oxford, UK.

Taylor, S., Castro, I. \& Griffiths, R. (2005) Hihi/Stitchbird (Notiomystis cincta) Recovery Plan 2004-09. Department of Conservation, Wellington, New Zealand.

Tompkins, D.M. \& Gleeson, D.M. (2006) Relationship between avian malaria distribution and an exotic invasive mosquito in New Zealand. Journal of the Royal Society of New Zealand, 36, 51-62.

Tomprins, D.M. \& Poulin, R. (2006) Parasites and biological invasions. In Biological Invasions in New Zealand (eds R.B. Allen \& W.G. Lee). Ecological Studies, 186, 67-84.

Tomprins, D.M., SAinsbury, A.W., Nettleton, P., Buxton, D. \& Gurnell, J. (2002) Parapoxvirus causes a deleterious disease in red squirrels associated with UK population declines. Proceedings of the Royal Society of London, Series B: Biological Sciences, 269, 529-533.

van Riper III, C., van Riper, S.G., Goff, M.L. \& Laird, M. (1986) The epizootiology and ecological significance of malaria in Hawaiian land birds. Ecological Monographs, 56, 327-344.

Viggers, K.L., Lindenmayer, D.B. \& Spratt, D.M. (1993) The importance of disease in reintroduction programmes. Wildlife Research, 20, 687-698.

Walker, S.F., Bosch, J., J ames, T.Y., Litvintseva, A.P., VAlls, J.A.O., PInA, S. et al. (2008) Invasive pathogens threaten species recovery programs. Current Biology, 18, 853-854.

Walter, D.E. \& Proctor, H.C. (1999) Mites: Ecology, Evolution and Behaviour. CABI, Wallingford, UK.

Williams, E.S., Mills, K., Kwiatkowski, D.R., Thorne, E.T. \& Boerger-Fields, A. (1994) Plague in a black-footed ferret (Mustela nigripes). Journal of Wildlife Diseases, 30, 581-585.

Woodford, M.H. (2001) Quarantine and Health Screening Protocols for Wildife Prior to Translocation and Release into the Wild. Conservation Breeding Specialist Group, IUCN Species Survival Commission, Gland, Switzerland, OIE, Paris, France, Care for the Wild, Horsham, UK, and the European Association of Zoo and Wildlife Veterinarians, Liebefeld-Serne, Switzerland. 


\section{Biographical sketches}

JоHN G. EWEN has been involved with hihi conservation since the mid 1990s. His research focuses on the management of populations founded through reintroduction. Doug P. ARMSTRONG's research focuses on the dynamics of small populations. He is chair of the Oceania Section of the IUCN/Species Survival Commission Reintroduction Specialist Group. RAEWYN EMPSON is conservation manager at Karori Sanctuary Trust and has a long-term interest in hihi management. SANDRA JACK has been involved in the field management of two hihi populations. Troy MAK AN was employed by Forest and Bird to review the hihi translocation in the Waitakere Ranges. Kate McInnes is wildlife veterinarian for the Department of Conservation. KEVIN A. PARKER's research focuses on the evolutionary implications of translocation. KATE RICHARDSON is researching post-release dispersal in hihi translocations. MAURICE AlLEY is a veterinary pathologist with a long-term interest in wildlife disease. 